\title{
Valuing map validation: The need for rigorous land cover map accuracy assessment in economic valuations of ecosystem services
}

Foody, G. M.

Ecological Economics, 111, 23-28 (2015)

The manuscript of the above article revised after peer review and submitted to the journal for publication, follows. Please note that small changes may have been made after submission and the definitive version is that subsequently published as:

Foody, G. M., 2015. Valuing map validation: The need for rigorous land cover map accuracy assessment in economic valuations of ecosystem services, Ecological Economics, 111, 23-28.

doi:10.1016/j.ecolecon.2015.01.003 


\title{
Valuing map validation: The need for rigorous land cover map accuracy assessment in economic valuations of ecosystem services
}

\author{
G. M. Foody \\ School of Geography \\ University of Nottingham \\ Nottingham \\ NG7 2RD \\ UK \\ E-mail: giles.foody@nottingham.ac.uk
}

\begin{abstract}
Valuations of ecosystem services often use data on land cover class areal extent. Area estimates from land cover maps may be biased by misclassification error resulting in flawed assessments and inaccurate valuations. Adjustment for misclassification error is possible for maps subjected to a rigorous validation program including an accuracy assessment. Unfortunately, validation is rare and/or poorly undertaken as often not regarded as a high priority. The benefit of map validation and hence its value is indicated with two maps. The International Geosphere Biosphere Programme's DISCover map was used to estimate wetland value globally. The latter changed from US\$1.92 trillion $\mathrm{yr}^{-1}$ to US $\$ 2.79$ trillion $\mathrm{yr}^{-1}$ when adjusted for misclassification bias. For the conterminous USA, ecosystem services value based on six land cover classes from the National Land Cover Database (2006) changed from US\$1118 billion $\mathrm{yr}^{-1}$ to US $\$ 600$ billion $\mathrm{yr}^{-1}$ after adjustment for misclassification bias. The effect of error-adjustment on the valuations indicates the value of map validation to rigorous evidence-based science and policy work in relation to aspects of natural capital. The benefit arising from validation was orders of magnitude larger than mapping costs and it is argued that validation should be a high priority in mapping programs and inform valuations.
\end{abstract}

Keywords: remote sensing, map accuracy, misclassification bias, valuation error. 


\section{Introduction}

It is now widely, but not universally, accepted that the benefits provided by ecosystems can be ascribed a monetary value (Costanza et al., 1998; Adams, 2014). These monetary estimates of the value of ecosystem goods and services should not be regarded as a price at which to trade but as a guide to the benefit that arises from aspects of natural capital that can aid activities such as policy formulation, decision-making and elements of natural accounting. A key role of the monetary estimates of ecosystem services obtained is in helping to communicate the value of the natural world and make informed decisions especially when competing uses require assessment (de Groot et al., 2012; Kubiszewski et al., 2013). To be useful in support of evidence-based decision making the estimates must, of course, be credible and accurate (Hauck et al., 2013; Schagner et al., 2013).

Determining the monetary value of ecosystem services is a challenging task (Costanza et al., 1997). However, one approach that has been widely used, especially in studies of very large regions, is to employ a simple benefit transfer method based on the areal extent of key land cover classes. In brief, the approach involves multiplying an estimate of the monetary value of the services provided by the land cover class per-unit area by the area of the land cover class in the region under consideration and summing values over all classes present (Costanza et al., 1997; Kreuter et al., 2001; Konarska et al., 2002; Kubiszewski et al., 2013). Although more sophisticated approaches that, for example, incorporate supply and value variables together have been developed recently (Ingraham and Foster, 2008; Maes et al., 2012; Schagner et al., 2013) it is still common for land cover to be used as a proxy variable in valuations of ecosystem services (Brown, 2013; Schagner et al., 2013). This type of approach can also be easily extended by incorporating spatially explicit information on relevant variables such as those that might lead to local fluctuations in the value of a site arising from its particular condition or of the beneficiaries of the ecosystem services (Troy and Wilson, 2006; Brander et al., 2012). Thus rather than apply a single value to all regions of a particular class a range of monetary values for key land cover classes may be used. The development of resources such as the Ecosystem Service Value Database may aid the selection 
of an appropriate monetary value per-unit area for a study (de Groot et al., 2012). None-the-less the basis of the approach is the simple benefit transfer method and this will be used throughout this article.

The land cover information required for valuations of ecosystem services may be obtained from maps produced via remote sensing. The latter is especially attractive as it offers the means to generate land cover data at a range of spatial and temporal scales. Remote sensing can, therefore, support the provision of land cover information to inform assessments for regions from the local through to the global scale that may, if desired, be updated in time. Although the approach is rather crude it provides a means to generate a first approximation for the value of ecosystem services (Costanza et al., 1997; Kubiszewski et al., 2013). Additionally, it is an approach that has been used to derive estimates for large areas, notably at the national and regional scale (Konarska et al., 2002; Kubiszewski et al., 2013) through to the global scale (Costanza et al., 1997) and to study changes in time (Kreuter et al., 2001; Costanza et al., 2014; Wang et al., 2014).

The quality of the estimates of the value of ecosystem services derived with the benefit transfer method is a function of the data used. A variety of issues have been highlighted with this approach to ecosystem services valuation, including issues connected with the land cover data and the monetary valuations associated with each class (e.g. Costanza et al., 1997; Kreuter et al. 2001; de Groot et al., 2012). This article focuses on the land cover data used as this can have a major impact on the valuation obtained. For example, Konarska et al. (2002) focus on a scale issue and report that for the same region, the conterminous USA, that the estimate of the value of ecosystem services differs by a factor of approximately three depending on the source of the land cover map used. Specifically, the use of a map with a $1 \mathrm{~km}$ spatial resolution yielded an estimate of ecosystem services value of US\$258 billion $\mathrm{yr}^{-1}$ and that this rose to US\$773 billion $\mathrm{yr}^{-1}$ if a more spatially detailed map with a $30 \mathrm{~m}$ spatial resolution was used. A key issue behind this result is that the accuracy of a land cover map, and hence estimates of class extent derived from it, will vary with the spatial resolution of the imagery used in its production. This is 
because the ability to detect and so to map a land cover patch is a function of its size relative to the spatial resolution of the sensor that acquired the imagery used for mapping; ideally patches should be larger than the pixel size of the imagery (Strahler et al., 1986; Woodcock and Strahler, 1987). The magnitude of the problem of mapping patches will vary as a function of the land cover mosaic on the ground and the spatial resolution of the imagery, being most severe for highly fragmented regions when using coarse spatial resolution imagery (Crapper, 1984; Foody et al., 1996). Since the areal extent of land cover classes can be greatly mis-estimated because of this problem (e.g. Skole and Tucker, 1993; Olofsson et al., 2013) methods to reveal sub-pixel scale land cover information via analyses such as soft classification and super-resolution mapping have become popular (Foody, 1996; Boucher et al., 2008; Muad and Foody, 2012; Su et al., 2012; Ling et al., 2013). However, the potential for error arising from other sources, notably thematic misclassification, remains.

The spatial resolution of the imagery used in mapping land cover is only one of a large number of issues that affect the accuracy of land cover maps and estimates of the areal extent of classes that can be derived from them. The spectral, temporal and radiometric resolutions of the sensor used to acquire the imagery, the classification algorithm used to produce the map, the ground reference data used to train and test the classification, and the thematic resolution of the map, for example, have a marked effect on mapping accuracy (Irons et al., 1985; Kenk et al., 1988; Gong and Howarth, 1990; Peddle et al., 1994; Arora and Foody, 1997; Foody, 2002; Lu and Weng, 2007; Kavzoglu 2009). There should be little surprise, therefore, that maps of the same area produced from different data sets or by different methods vary in their representation and hence could yield dissimilar estimates of ecosystem services value. What may be less obvious is that very dissimilar estimates of ecosystem services value can be obtained from the same map.

A map is a generalization and will, therefore, be expected to contain error. However, in the calculation of ecosystem services value by the simple benefit transfer method discussed above, land cover maps have 
been taken, essentially, at face value. That is, the map is used as a representation of the land cover and areal extent measured directly from it. For example, the areal extent of the land cover classes for ecosystem services valuations in studies such as Konarska et al. (2002) was derived by counting all the image pixels allocated to each class. Even if a map is highly accurate this approach can result in large mis-estimation of class area (Olofsson et al., 2013). This type of problem arises especially when misclassification errors are asymmetric, with, for example, imbalanced errors of omission and commission. If, however, the error is known and characterised its effects can be accounted for (Staquet et al., 1982; Foody, 2010). A variety of approaches to correct for the effects of mis-classification bias in order to derive accurate areal estimates have been discussed in the remote sensing literature (Card, 1982; Hay, 1988; Czaplewski, 1992; Gallego, 2004; McRoberts, 2010; Stehman, 2013). Critically, adjustment for misclassification error allows accurate estimates of class areal extent to be obtained even if the map is itself not highly accurate in its representation of the land cover. The information required to adjust estimates of class areal extent for misclassification error can be derived from a standard confusion matrix that is generated in a validation program to assess the accuracy of the land cover map. Although the assessment and interpretation of map accuracy is itself far from a trivial activity (Foody 2002, 2008) it can, if undertaken rigorously, yield information to aid accurate area estimation in addition to a description of map accuracy (Stehman, 2012; Olofsson et al., 2013, 2014). Unfortunately, validation is commonly not viewed as a high priority in mapping land cover from remote sensing and many maps are not, or only poorly, validated (Olofsson et al., 2013) which greatly compromises their utility.

Attitudes to map validation may change if a monetary value could be ascribed to the benefit that arises from undertaking it. This has been the case with studies of ecosystem goods and services with estimates of the benefits that arise from these components of natural capital helping to inform decision making and policy. Ecosystem services also provide a basis to indicate the monetary value of map validation as land cover extents are used in valuations. This paper aims to illustrate the value or importance of map validation to the estimation of the value of ecosystem services. It will illustrate the effects of mis- 
classification error on class areal estimates and hence the valuation of ecosystem services. The difference between the valuations obtained with the use of the original mapped areas and that from the erroradjusted areas will be used to give a guide to the benefit that arises from a rigorous validation program that provides information on map accuracy. The derived values will be put in the context of the financial costs of other parts of a major mapping program to illustrate the size of the benefit arising from a validation program relative to the cost of its undertaking.

\section{Materials and Methods}

The approach discussed by Card (1982) to adjust class area estimates for misclassification error was adopted as it is easy to use and fits with recommended good practice for the assessment and use of land cover maps derived from remote sensing (Strahler et al., 2006; Olofsson, et al., 2013, 2014). With this approach the misclassification error-adjusted estimates of area are derived from the confusion matrix that is often central to map validation programs as it forms the basis for the estimation of map accuracy.

The confusion matrix is a cross-tabulation of the class label shown in the map against that in a reference data set for a sample of units selected in a validation program (Table 1). Ideally the sample of units (e.g. pixels) for the accuracy assessment will be independent from any used in the training of the classifier that was used to produce the map and be acquired in a carefully designed manner. The latter includes ideally the use of a probability sampling design such as random, systematic or stratified sampling. The actual land cover class of each sample unit selected should be determined to form the reference data set to use in generating the confusion matrix that summarises the quality of the map and from which estimates of map accuracy and class areal extent may be obtained. Further details on the nature of a validation program for accuracy assessment and area estimation are given in the literature (e.g. Stehman and Czaplewski, 1997;

Stehman, 1999; Strahler et al., 2006; Stehman and Foody, 2009; Olofsson et al., 2013) with good practices summarised in Olofsson et al. (2014). 
Here, two land cover maps were used. In each case the validation programme included an accuracy assessment based upon stratified random sampling. In this situation, the key information for the estimation of a mis-classification error corrected estimate of class areal extent is summarized in Table 1. The latter is in essence, the confusion matrix plus information on the extent of each class in the map. From Table 1, an unbiased estimator of the areal extent of class $j$ in the map may be obtained from

$$
\hat{A}_{j}=A_{\text {total }} \sum_{i} W_{i} \frac{n_{i j}}{n_{i \cdot}}
$$

in which $A_{\text {total }}$ is the total area mapped, $W_{i}$ is the proportion of the total area mapped that is represented as belonging to class $i, n_{i j}$ are the counts of cases lying within the designated element of the confusion matrix, $n_{i \cdot}$ and $n_{\cdot i}$ are the sum of the counts in the relevant row and column of the matrix respectively and $n$ the total number of sample units used to construct the confusion matrix (Olofsson et al., 2013). For an individual class, attention focuses on the column of the confusion matrix associated with the class for the provision of the relevant information on $\frac{n_{i j}}{n_{i}}$ and the associated $W_{i}$ values.

To simplify analyses, the approach adopted by studies such as Konarska et al. (2002) and Kubiszewski et al. (2013) was followed closely. Specifically the same land cover classes and ecosystem services values as used by Konarska et al. (2002) (Table 2), which are based on valuation coefficients used in earlier research (e.g. Costanza et al., 1997), were used throughout to aid a simple, if superficial, assessment of the importance of correction for misclassification error in area estimation and hence for map validation.

The two land cover data sets used are freely available and are the same or similar to those that have been used in other studies of ecosystem service valuation. These data sets are the International Geosphere Biosphere Programme's (IGBP) DISCover global land cover map (Belward et al., 1999) and the map for the conterminous USA for 2006 from the National Land Cover Database (NLCD; Fry et al., 2011). 
Critical to their selection is the availability for each of information arising from a rigorous validation program, notably a confusion matrix.

The IGBP map depicts the geographical distribution of 17 land cover classes for the entire globe (Table 2). This map was produced in the 1990s from NOAA AVHRR data with a spatial resolution of $1 \mathrm{~km}$. Details on the map and its production may be found in Loveland et al. (1999). There are many issues to consider in an accuracy assessment and it can be approached in a variety of ways. In the validation of the IGBP map, three expert image interpreters were used to form the reference data set (Scepan, 1999). Here, the confusion matrix derived following majority decision rule, using only the reference data units upon which at least two of the expert interpreters agreed on a class label, was used (Scepan, 1999; DeFries and Los, 1999). This matrix suggests that the map has an accuracy of $73.5 \%$. Although the validation programme was immensely useful there are some concerns. For example, the size of the sample used was small, especially for some classes and two classes (snow and ice, and water) were not included fully in the validation (Scepan, 1999). To try and minimise the effects of these problems attention is focused here on just the wetland class. This class was selected since it has associated with it a high ecosystem services value and also the confusion matrix does not indicate significant error linked to the classes excluded from the validation program.

The NLCD map of 2006 was used to repeat the analysis of Konarska et al. (2002) which was based on the earlier map for 1992. The NLCD map for 2006 shows the spatial distribution of 16 land cover classes over the conterminous USA and was derived from Landsat TM data with a spatial resolution of 30m (Fry et al., 2011). Unlike the earlier version, the 2006 map was subject to a rigorous validation program. Key details on this, including confusion matrix is given by Wickham et al. (2013). Here, the published estimates of class areal extent (obtained from: http://www.mrlc.gov/nlcd06_stat.php ) together with revised areal estimates after adjustment for misclassification error (Wickham et al., 2013; Table 6 page 300) were used. The land cover classes were aggregated to a more general set of six classes (Anderson 
level I) and the same ecosystem services values used as those in Konarska et al. (2002); the classes and associated value data used are summarised in Table 2.

With each map, estimates of the ecosystem services value were derived using the mapped area and the misclassification error-adjusted area based on equation 1.

\section{Results and Discussion}

The IBGP map shows $1.3 \times 10^{8}$ ha $\left(1.3 \times 10^{6} \mathrm{~km}^{2}\right)$ of wetland. Using this mapped extent and a value of $\$ 14785 \mathrm{ha}^{-1} \mathrm{yr}^{-1}$ yields an estimate of the global value of the ecosystem services provided by wetlands of US\$1.92 trillion (i.e. $1.92 \times 10^{12}$ ) $\mathrm{yr}^{-1}$. This estimate, however, ignores the effects of misclassification error that is captured in the confusion matrix.

Table 3 summarises the information required for the calculation of a misclassification error-adjusted estimate of wetland area with equation 1 derived from the confusion matrix (further details and the matrix are published in Scepan, 1999 and DeFries and Los, 1999). In particular, the use of the mapped areal extent in the estimation ignores the observation that several cases of wetland were commissioned by other classes. Specifically, of the sample used for accuracy assessment, 1 of 20 cases mapped as evergreen needleleaf forest (i.e. $\frac{n_{i j}}{n_{i}}=0.05$; Table 3), 1 of 24 cases mapped as evergreen broadleaf forest, 2 of 9 cases mapped as deciduous needleleaf forest, and 1 of 20 cases mapped as closed shrubland were all actually cases of wetland. The estimate of ecosystem services value for wetlands globally obtained after adjustment for misclassification error with equation 1 was US $\$ 2.79$ trillion $\mathrm{yr}^{-1}$. Thus, in this example, the failure to adjust for known misclassification error characterised in the confusion matrix resulted in the ecosystem services value being greatly underestimated, with the estimate based on the original mapped class area being approximately two-thirds of the value obtained using the error-adjusted estimate. 
The summary statistics on the areal extent of each class in the NLCD data are reproduced in Table 4. As previously these estimates were derived directly from the map and make no account for the effect of misclassification error. Although this is a relatively accurate map, with an estimated accuracy of $84 \%$ (Wickham et al., 2013; for the map at Anderson level I), the effect of misclassification error can still be large and was explored. For this, error-adjusted estimates of class extent are required. The latter are provided by Wickham et al. (2013) and also reproduced in Table 4. Estimates of the value of ecosystem services for the conterminous USA were obtained using the original mapped areal extents and the misclassification error-adjusted estimates of class area. It was apparent that by taking the map at face value, the estimate of ecosystem services value for the conterminous USA was $\sim$ US $\$ 1118$ billion $\mathrm{yr}^{-1}$. This is substantially larger than the US $\$ 773$ billion $\mathrm{yr}^{-1}$ reported by Konarska et al. (2002) based on the earlier NLCD map for 1992. Given that the monetary value per-unit area associated with each class was constant, this outcome could indicate a substantial increase in the value of ecosystem services and might perhaps be interpreted as reflecting the results of successful policy outcomes or some other change that acted to increase the extent of wetlands. Alternatively, the difference in the valuations may actually be of uncertain meaning because the estimates themselves have not been corrected for misclassification error. The latter is possible for the 2006 map because of the rigorous accuracy assessment undertaken (Wickham et al., 2013). The estimate of ecosystem services value arising after misclassification erroradjustment was $\sim$ US $\$ 600$ billion $\mathrm{yr}^{-1}$ (Table 4). The $\sim$ US\$518 billion $\mathrm{yr}^{-1}$ difference between the original and error-adjusted estimates highlights the importance of rigorous map validation to accurate evidencebased science and guidance on the value of map validation. In essence, by failing to correct for the effect of misclassification error, even when using a relatively accurate map, the estimates of the value of ecosystem services were inflated by a factor of 1.86 . For estimates of ecosystem services value to be useful in terms of informing evidence-based policy work it is important that the estimates be accurate and this requires that the effects of known error sources be accounted for when possible. In this way map validation can add value to studies of ecosystem services. 
Although the indicated monetary values are only crude estimates, the magnitude of the difference between the valuation based on the original mapped area estimates and that from the misclassification error-adjusted area estimates indicates the benefit and so the importance or value of map validation to valuations of ecosystem services. The value of the validations indicated vastly exceeds the well-known and defined costs of major mapping programmes. For example, a key part of a major mapping programme such as that associated with the NLCD products is the satellite remote sensing system used: Landsat. The financial cost of a Landsat satellite over its typical $\sim 5$ year life-cycle, including design, launch and data management, is in the order of US\$ 1 billion (National Research Council, 2013). The actual costs of mapping from such remotely sensed data are also relatively low. For example, Franklin et al. (2000) report that the cost of mapping is in the order of US\$ $0.35 \mathrm{ha}^{-1}$, an order of magnitude cheaper than mapping via interpretation of aerial photographs and fieldwork; the costs vary greatly between sensing systems with the costs of data acquisition and processing being least for coarse spatial resolution systems (Rogan and Chen, 2004). Little explicit mention to the costs of validation is provided in the literature but, as context, the total cost of developing and validating the IGBP map was less than US\$ 500,000 (Belward et al., 1999), although the bodies involved will have contributed in-kind.

The quality of ecosystem services valuations is influenced by a variety of factors. With the simple benefit transfer method, the quality of the valuation obtained is clearly a function of both the accuracy of the land cover class areal extent data and the set of valuation coefficients used. Error and uncertainty linked to one or both of these variables could substantially degrade the quality of a valuation. In this article, only the effect of misclassification error in the land cover map used in a basic benefit transfer method for ecosystem services valuation has been addressed. There are a variety of additional variables that impact on the accuracy of land cover maps and the estimates of class area that may be obtained from them. For example, the presence of even very small error in the reference data set used in the validation can be a source of substantial error in terms of accuracy assessment and area estimation (Carlotto, 2009; Foody, 2010, 2013). If the full potential of remote sensing as a source of accurate information on land cover is to 
be realised it is, therefore, vital that maps are validated, which typically means that the validation program that provides the accuracy information is undertaken with considerable care and uses high quality data. Given that accuracy assessment is not a trivial task and also of fundamental importance to the derivation of accurate information it should be given a high priority in mapping projects. As a guide to what may be required, Strahler et al (2006) urge that validation form about a third of a global scale land cover mapping program.

\section{Conclusions}

Estimates of the areal extent of land cover classes are often used in the calculation of the value of ecosystem services. These estimates of class extent are often derived directly from a land cover map, commonly produced via remote sensing. Even if a land cover map is of a high accuracy the direct estimation of class areal extent from it may be highly erroneous due to the effect of misclassification errors. The effect of the latter, however, can be addressed if the accuracy of the map has been rigorously evaluated as part of a map validation program. Information on the magnitude and pattern of classification error allows the derivation of error-adjusted class area estimates. The latter may differ greatly from the original estimates of class area obtained directly from the map and so impact substantially on the estimation of ecosystem services value derived with the use of the map. Here, the availability of information on classification accuracy was found to result in very substantial changes to ecosystem services valuations. The magnitude of the difference in valuations arising from the use of the original and error-adjusted estimates indicates the benefit that arises from a rigorous map validation program. In the examples given, the magnitude of this benefit was large, orders of magnitude greater than the cost of producing the map (including the satellite system from which the remotely sensed imagery were obtained). Validation provides information to allow maps to be used effectively as a source of information on class area to usefully inform evidence-based research and policy activities and hence should be accorded a high priority in mapping programs. 


\section{Acknowledgements}

I am grateful to those involved in the production and evaluation of the IGBP and NLCD maps used as well as the two anonymous referees for their helpful review comments.

\section{References}

Adams, W. M., 2014. The value of valuing nature. Science, 346, 549-551.

Arora, M.K., Foody, G.M., 1997. Log-linear modelling for the evaluation of the variables affecting the accuracy of probabilistic, fuzzy and neural network classifications. International Journal of Remote Sensing, 18, 785-798.

Belward, A.S., Estes, J. E., Kilne, K. D., 1999. The IGBP-DIS global 1-km land-cover data set DISCover: a project overview. Photogrammetric Engineering and Remote Sensing, 65, 1013-1020.

Boucher, A., Kyriakidis, P. C., Cronkite-Ratcliff, C., 2008. Geostatistical solutions for super-resolution land cover mapping. IEEE Transactions on Geoscience and Remote Sensing, 46, 272-283.

Carlotto, M. J. 2009. Effect of errors in groud truth on classification accuracy. International Journal of Remote Sensing, 30, 4831-4849.

Brander, L. M., Wagtendonk, A. J., Hussain, S. S., McVittie, A., Verburg, P. H., De Groot, R. S., Van Der Ploeg, S. W. F., 2012. Ecosystem service values for mangroves in Southeast Asia: A meta-analysis and value transfer application. Ecosystem Services, 1, 62-69.

Brown, G. G., 2013. The relationship between social values for ecosystem services and global land cover: An empirical analysis. Ecosystem Services, 5, 58-68. 
Card, D. H., 1982. Using map category marginal frequencies to improve estimates of thematic map accuracy. Photogrammetric Engineering and Remote Sensing, 49, 431-439

Costanza, R., d’Arge, R., de Groot, R., Farber, S., Grasso, M., Hannon, B., Limburg, K., Naeem, S., O’Neill, R. V., Parueio, J., Raskin, R. G., Sutton, P., van den Belt, M., 1997. The value of the world's ecosystem services and natural capital. Nature, 387, 253-260.

Costanza, R., d'Arge, R., de Groot, R., Farber, S., Grasso, M., Hannon, B., Limburg, K., Naeem, S., O’Neill, R. V., Parueio, J., Raskin, R. G., Sutton, P., van den Belt, M., 1998. The value of ecosystem services: putting the issues in perspective. Ecological Economics, 25, 67-72.

Costanza, R., de Groot, R., Sutton, P., van der Ploeg, S., Anderson, S. J., Kubiszewski, I., Farber, S., Turner, R. K., 2014. Changes in the global value of ecosystem services. Global Environmental Change Human and Policy Dimensions, 26, 152-158.

Crapper, P. F., 1984. An estimate of the number of boundary cells in a mapped landscape coded to grid cells. Photogrammetric Engineering and Remote Sensing, 50, 1497-1503.

Czaplewski, R. L., 1992. Misclassification bias in areal estimates. Photogrammetric Engineering and Remote Sensing, 58, 189-192.

DeFries, R. S., Los, S. O., 1999. Implications of land-cover misclassification for parameter estimates in global land-surface models: an example from the simple biosphere model (SiB2). Photogrammetric Engineering and Remote Sensing, 65, 1083-1088. 
de Groot, R, Brander, L., van der Ploeg, S., Costanza, R., Bernard, F., Braat, L., Christie, M., Crossman, N., Ghermandi, A., Hein, L., Hussain, S., Kumar, P., McVittie, A., Portela, R., Rodriguez, L. C., ten Brink, P., van Beukering, P., 2012. Global estimates of the value of ecosystems and their services in monetary units. Ecosystem Services, 1, 50-61.

Foody, G.M., 1996. Approaches for the production and evaluation of fuzzy land cover classifications from remotely sensed data. International Journal of Remote Sensing, 17, 1317-1340.

Foody, G. M., 2002. Status of land cover classification accuracy assessment. Remote Sensing of Environment, 80, 185-201.

Foody, G. M., 2008. Harshness in image classification accuracy assessment. International Journal of Remote Sensing, 29, 3137-3158.

Foody, G. M., 2010. Assessing the accuracy of land cover change with imperfect ground reference data. Remote Sensing of Environment, 114, 2271-2285.

Foody, G. M. 2013. Ground reference data error and the mis-estimation of the area of land cover change as a function of its abundance. Remote Sensing Letters, 4, 783-792.

Foody, G.M., Lucas, R.M., Curran, P.J., Honzák, M., 1996. Estimation of the areal extent of land cover classes that only occur at a sub-pixel level. Canadian Journal of Remote Sensing, 22, 428-432.

Franklin, J., Woodcock, C. E., Warbington, R., 2000. Multi-attribute vegetation maps of forest service lands in California supporting resource management decisions. Photogrammetric Engineering and Remote Sensing, 66, 1209-1217. 
Fry, J., Xian, G., Jin, S., Dewitz, J., Homer, C., Yang, L., Barnes, C., Herold, N., Wickham, J., 2011. Completion of the 2006 National Land Cover Database for the Conterminous United States.

Photogrammetric Engineering and Remote Sensing, 77, 858-864.

Gallego, F. J., 2004. Remote sensing and land cover area estimation. International Journal of Remote Sensing, 25, 3019-3047.

Gong, P., Howarth, P. 1990. An assessment of some factors influencing multispectral land-cover classification. Photogrammetric Engineering and Remote Sensing, 56, 597-603.

Hauck, J., Görg, C., Varjopuro, R., Ratamäki, O., Maes, J., Wittmer, H., Jax, K., 2013. "Maps have an air of authority": Potential benefits and challenges of ecosystem service maps at different levels of decision making. Ecosystem Services, 4, 25-32.

Hay, A.M., 1988. The derivation of global estimates from a confusion matrix. International Journal of Remote Sensing, 9:1395-1998.

Ingraham, M. W., Foster, S. G., 2008. The value of ecosystem services provided by the U.S. National Wildlife Refuge System in the contiguous U.S. Ecological Economics, 67, 608-618.

Irons, J. R., Markham, B. L., Nelson, R. F., Toll, D. L., Williams, D. L., 1985. The effects of spatial resolution on the classification of Thematic Mapper data. International Journal of Remote Sensing, 6, $1385-1403$. 
Kavzoglu, T. 2009. Increasing the accuracy of neural network classification using refined training data. Environmental Modelling and Software, 24, 850-858.

Kenk, E., Sondheim, M., Yee, B., 1988. Methods for improving accuracy of thematic mapper ground cover classification. Canadian Journal of Remote Sensing, 14, 17-31

Konarska, K. M., Sutton, P. C., Castellon, M., 2002. Evaluating scale dependence of ecosystem service valuation: a comparison of NOAA-AVHRR and Landsat TM data sets. Ecological Economics, 41, 491507.

Kreuter, U. P., Harris, H. G., Matlock, M. D., Lacey, R. E., 2001. Change in ecosystem service values in the San Antonio area, Texas. Ecological Economics, 39, 333-346.

Kubiszewski, I., Costanza, R., Dorji, L., Thoennes, P., Tshering, K., 2013. An initial estimate of the value of ecosystem services in Bhutan. Ecosystem Services, 3, e11-e21.

Ling, F., Du, Y., Li, X., Li, W., Xiao, F., Zhang, Y. 2013. Interpolation-based super-resolution land cover mapping. Remote Sensing Letters, 4, 629-638.

Loveland, T. R., Zhu, Z., Ohlen, D. O., Brown, J. F., Reed, B. C., Yang, L., 1999. An analysis of the IGBP global land-cover characterisation process. Photogrammetric Engineering and Remote Sensing, 65, $1021-1032$.

Lu, D., Weng, Q. 2007. A survey of image classification methods and techniques for improving classification performance. International Journal of Remote Sensing, 28, 823-870. 
McRoberts, R. E., 2010. Probability- and model-based approaches to inference for proportion forest using satellite imagery as ancillary data. Remote Sensing of Environment, 114, 1017-1025.

Maes, J., Egoh, B. N., Willemen, L., Liquete, C., Vihervaara, P., Schägner, J.P., Grizzetti, B., Drakou, E. G., La Notte, A., Zulian, G., Bouraoui, F., Paracchini, M. L., Braat, L. C., Bidoglio, G., 2012. Mapping ecosystem services for policy support and decision making in the European Union. Ecosystem Services, $1,31-39$

Muad, A. M. and Foody, G. M., 2012. Impact of land cover patch size on the accuracy of patch area representation in HNN-based super resolution mapping. IEEE Journal of Selected Topics in Applied Earth Observations and Remote Sensing, 5, 1418-1427.

National Research Council, 2013. Landsat and Beyond - Sustaining and Enhancing the Nation's Land Imaging Program, National Academies Press, Washington D.C.

Olofsson, P., Foody, G. M., Stehman, S. V., Woodcock, C. E., 2013. Making better use of accuracy data in land change studies: estimating accuracy and area and quantifying uncertainty using stratified estimation. Remote Sensing of Environment, 129, 122-131.

Olofsson, P., Foody, G. M., Herold, M., Stehman, S. V. Woodcock, C. E., Wulder, M. A., 2014. Good practices for assessing accuracy and estimating area of land change. Remote Sensing of Environment, $148,42-57$.

Peddle, D.R., Foody, G.M., Zhang, A., Franklin, S.E., LeDrew, E.F., 1994. Multisource image classification II: an empirical comparison of evidential reasoning and neural network approaches. Canadian Journal of Remote Sensing, 20, 396-407. 
Rogan, J. and Chen, D., 2004. Remote sensing technology for mapping and monitoring land-cover and land-use change. Progress in Planning, 61, 301-325.

Scepan, J., 1999. Thematic validation of high-resolution global land-cover data sets. Photogrammetric Engineering and Remote Sensing, 65, 1051-1060.

Schägner, J. P., Brander, L. M., Maes, J., Hartje, V., 2013. Mapping ecosystem services' values: Current practice and future prospects. Ecosystem Services, 4, 33-46.

Skole, D., Tucker, C., 1993. Tropical deforestation and habitat fragmentation in the Amazon. Satellite data from 1978 to 1988 . Science, 260, 1905-1910.

Staquet, M., Rozencweig, M., Lee, Y. J.,Muggia, F. M., 1981. Methodology for the assessment of new dichotomous diagnostic tests. Journal of Chronic Diseases, 34, 599-610.

Stehman, S. V., 1999. Basic probability sampling designs for thematic map accuracy assessment. International Journal of Remote Sensing, 20, 2423-2441.

Stehman, S. V. 2012. Impact of sample size allocation when using stratified random sampling to estimate accuracy and area of land-cover change. Remote Sensing Letters, 3, 111-120.

Stehman, S. V., 2013. Estimating area from an accuracy assessment error matrix. Remote Sensing of Environment, 132, 202-211. 
Stehman, S. V., Czaplewski, R. L., 1998. Design and analysis for thematic map accuracy assessment: fundamental principles. Remote Sensing of Environment, 64, 331-344.

Stehman, S. V., Foody, G. M., 2009. Accuracy assessment, In Warner, T. A., Nellis, M. D and Foody, G. M. (editors) The SAGE Handbook of Remote Sensing, Sage, London, 297-309.

Strahler, A. H., Boschetti, L., Foody, G. M., Friedl, M. A., Hansen, M. C., Herold, M., Mayaux, P., Morisette, J. T., Stehman, S. V., Woodcock, C. E., 2006. Global Land Cover Validation: Recommendations for Evaluation and Accuracy Assessment of Global Land Cover Maps. European Commission, Joint Research Centre, Ispra, Italy, EUR 22156 EN, 48pp.

Strahler, A. H., Woodcock, C. E., Smith, J. A., 1986. On the nature of models in remote sensing. Remote Sensing of Environment, 20, 121-139.

Su, Y-F, Foody, G. M., Muad, A. M., Cheng, K-S, 2012. Combining Hopfield neural network and contouring methods to enhance super-resolution mapping, IEEE Journal of Selected Topics in Applied Earth Observation and Remote Sensing, 5, 1403-1417.

Troy, A., Wilson, M. A., 2006. Mapping ecosystem services: practical challenges and opportunities in linking GIS and value transfer. Ecological Economics, 60, 435-449.

Wang, Y., Gao, J., Wang, J., Wu, Y., Zou, C., Tian, M., Zheng, H., 2014, Evaluating losses in ecosystem services in nature reserves in Sichuan, China. International Journal of Sustainable Development and World Ecology, 21, 290-301. 
Wickham, J.D., Stehman, S.V., Gass, L., Dewitz, J., Fry, J.A., Wade, T.G., 2013. Accuracy assessment of NLCD 2006 land cover and impervious surface. Remote Sensing of Environment, 130, 294-304.

Woodcock, C. E., Strahler, A. H., 1987. The factor of scale in remote sensing. Remote Sensing of Environment, 21, 311-332. 


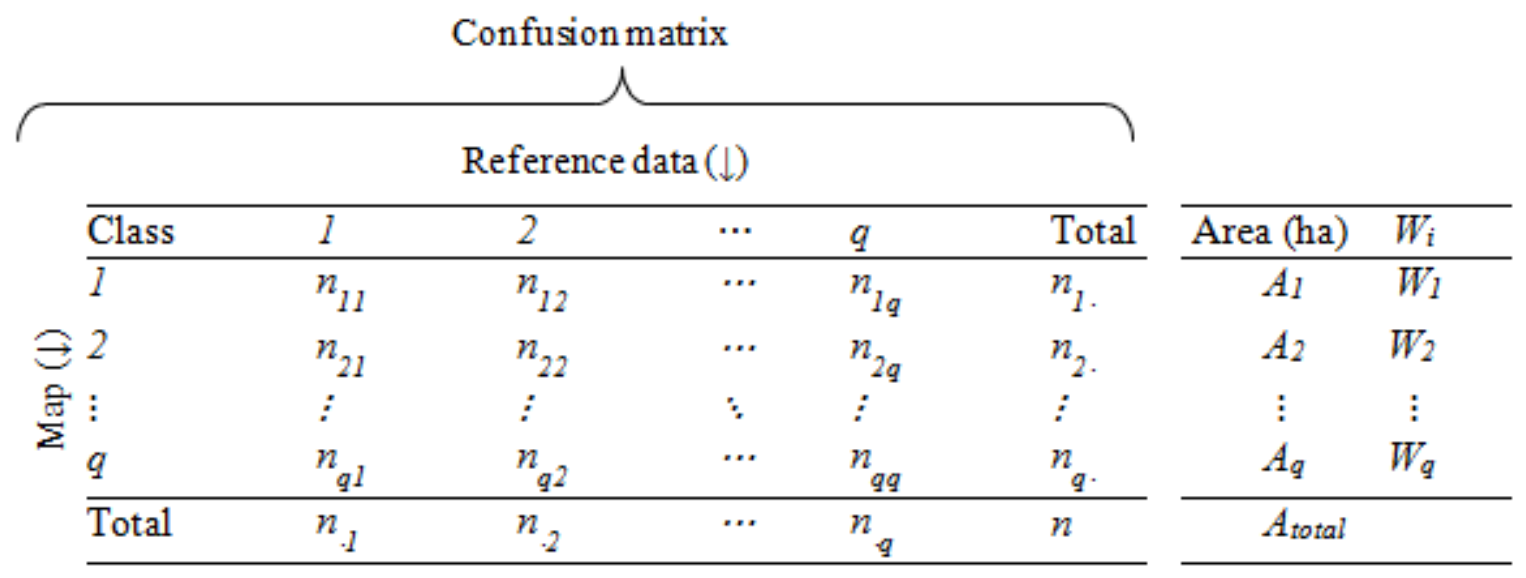

Table 1. The confusion matrix used in accuracy assessment and additional information required to obtain a misclassification error adjusted estimate of class area using equation 1. 


\begin{tabular}{|c|c|c|c|}
\hline IGBP & NLCD & Aggregated & Value (US\$ ha ${ }^{-1} \mathrm{yr}^{-1}$ ) \\
\hline $\begin{array}{l}\text { Evergreen Needleleaf Forest } \\
\text { Evergreen Broadleaf Forest } \\
\text { Deciduous Needleleaf Forest } \\
\text { Deciduous Broadleaf Forest } \\
\text { Mixed Forest } \\
\end{array}$ & $\begin{array}{l}\text { Deciduous Forest } \\
\text { Evergreen Forest } \\
\text { Mixed Forest }\end{array}$ & Forest & 302 \\
\hline $\begin{array}{l}\text { Closed Shrublands } \\
\text { Open Shrublands } \\
\text { Woody Savannas }\end{array}$ & Shrublands & Shrublands & 267 \\
\hline $\begin{array}{l}\text { Savannas } \\
\text { Grasslands }\end{array}$ & Grasslands/herbaceous & Grasslands & 232 \\
\hline Permanent Wetlands & $\begin{array}{l}\text { Woody Wetlands } \\
\text { Herbaceous Wetlands }\end{array}$ & Wetlands & 14785 \\
\hline $\begin{array}{l}\text { Croplands } \\
\text { Cropland/Natural Vegetation } \\
\text { Mosaic }\end{array}$ & $\begin{array}{l}\text { Pasture/Hay } \\
\text { Row Crops }\end{array}$ & Croplands & 92 \\
\hline Water Bodies & Water & Water & 8498 \\
\hline Urban and Built-Up & $\begin{array}{l}\text { Low Intensity Residential } \\
\text { High Intensity Residential } \\
\text { Commercial/Industrial/Transportation } \\
\text { Developed High Intensity }\end{array}$ & & 0 \\
\hline Snow and Ice & Perennial Ice/Snow & - & 0 \\
\hline Barren or Sparsely Vegetated & Bare Rock/Sand/Clay & - & 0 \\
\hline
\end{tabular}

Table 2. The land cover classes depicted on the IGBP and NLCD maps used together with the aggregated versions used in the valuations of ecosystem services reported. The monetary values or valuation coefficients used are those adopted in other studies such as Costanza et al. (1997) and Konarska et al. (2002). 


\begin{tabular}{|l|c|c|}
\hline Class & $\frac{n_{i j}}{n_{i-}}$ & $W_{i}$ \\
\hline Evergreen Needleleaf Forest & 0.05 & 0.04375 \\
\hline Evergreen Broadleaf Forest & 0.0417 & 0.082967 \\
\hline Deciduous Needleleaf Forest & 0.2222 & 0.013462 \\
\hline Closed Shrublands & 0.05 & 0.01772 \\
\hline Wetland & 0.3846 & 0.008929 \\
\hline
\end{tabular}

Table 3.Data used to obtain a misclassification error adjutsed estimate of wetland area with equation 1. The column of $\frac{n_{i j}}{n_{i-}}$ values and the $W_{i}$ values are based on the wetland column of the confusion matrix for the IGBP map and summary statistics on class coverage provided by DeFries and Los (1999; tables 2 and 4). 


\begin{tabular}{|c|c|c|c|c|}
\hline & \multicolumn{2}{|c|}{ Mapped area } & \multicolumn{2}{|c|}{ Misclassification error-adjusted } \\
\hline Class & Mapped area, \% (ha) & $\begin{array}{l}\text { Ecosystem } \\
\text { services value } \\
\text { US\$ billion } \mathrm{yr}^{-1} \\
\end{array}$ & $\begin{array}{l}\text { Misclassification error } \\
\text { adjusted area, \% (ha) }\end{array}$ & $\begin{array}{l}\text { Ecosystem } \\
\text { services value } \\
\text { US\$ billion } \mathrm{yr}^{-1}\end{array}$ \\
\hline Forest & $24.95 \quad(201607551.85)$ & 60.88 & $29.75 \quad(240353371.94)$ & 72.59 \\
\hline Shrublands & $21.36 \quad(172598689.68)$ & 46.08 & $\begin{array}{|ll|}21.40 & (172929988.66)\end{array}$ & 46.17 \\
\hline Grasslands & $14.47 \quad(116924299.61)$ & 27.13 & $12.74 \quad(102961259.55)$ & 23.89 \\
\hline Croplands & $22.24 \quad(179709497.12)$ & 16.53 & $24.42 \quad(197316826.00)$ & 18.15 \\
\hline Wetlands & $(41371970.56)$ & 611.68 & $(19780973.42)$ & 292.46 \\
\hline Water & $(41856798.34)$ & 355.70 & $(17372995.45)$ & 147.63 \\
\hline
\end{tabular}

Table 4. Estimtes of the value of ecosystem services for the conterminous USA based on the mapped area (using summary statistics provided at the internet site from which the NLCD data may be downloaded: http://www.mrlc.gov/nlcd06_stat.php) and misclassification error-adjusted area estimates (using Wickham et al. (2013), table 6). 